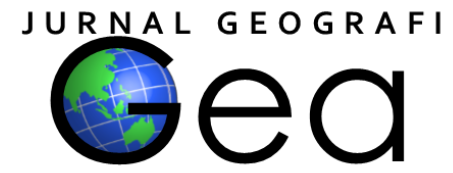

\title{
ANALISIS PASCA BENCANA TANAH LONGSOR 1 JANUARI 2020 DAN EVALUASI PENATAAN KAWASAN DI KECAMATAN SUKAJAYA, KABUPATEN BOGOR
}

\author{
Heru Sri Naryanto ${ }^{1}$, Firman Prawiradisastra ${ }^{2}$, Ruki Ardiyanto ${ }^{3}$, Wahyu Hidayat ${ }^{4}$ \\ ${ }^{1,2}$ Pusat Teknologi Reduksi Risiko Bencana, ${ }^{3}$ Pusat Teknologi Pengembangan Sumberdaya \\ Wilayah, ${ }^{4}$ Pusat Teknologi Pengembangan Sumberdaya Mineral, \\ Badan Pengkajian dan Penerapan (BPPT), Gedung Geostech, Kompleks Puspiptek Serpong, \\ Kota Tangerang Selatan, Provinsi Banten, Indonesia \\ 1heru.naryanto@bppt.go.id, ${ }^{2}$ firman.prawiradisastra@bppt.go.id, ${ }^{3}$ ruki.ardiyanto@bppt.go.id, \\ wahyu.hidayat@bppt.go.id
}

\begin{abstract}
Landslides are increasingly occurring lately in Bogor District, including in Sukajaya Sub District. Landslides have occurred massively, comprehensively and at the same time in Sukajaya Sub District, on January 1, 2020. Sukajaya Sub District is included in a high landslide hazard zone. Many factors cause landslides in Sukajaya Sub District, namely: slope, geological and soil conditions, land use, drainage patterns, rainfall, and human activities. The most influential dominant factors are: extreme daily rainfall before and during landslides, types of volcanic rock that form very thick and loose soil, and steep-very steep slopes. Analysis of various factors causing landslides, landslide zoning and analysis of landslide mechanisms, will greatly assist in handling and anticipating future disasters. Arrangement of the area after a landslide is very necessary to be able to reduce the risk of disasters and build a sustainable safe area. Many things that can be done in the arrangement of the landslide area include: former and landslide-prone areas made conservation areas, relocation of threatened populations to safe places, drainage arrangements, strengthening of cliffs and road slopes, avoiding living on hill slopes and river courses, greening with hard plants and strong roots. The formation of community preparedness is also needed to form a community that is resilient to landslides.
\end{abstract}

Keywords: Sukajaya, landslides, extreme rainfall, rock and soil, regional arrangement

\begin{abstract}
ABSTRAK
Bencana tanah longsor semakin sering terjadi akhir-akhir ini di Kabupaten Bogor termasuk di Kecamatan Sukajaya. Bencana longsor telah terjadi secara masif, menyeluruh dan waktu yang bersamaan di Kecamatan Sukajaya, pada tanggal 1 Januari 2020. Kecamatan Sukajaya termasuk dalam zona bahaya tanah longsor tinggi. Banyak faktor yang menyebabkan terjadinya tanah longsor di Kecamatan Sukajaya, yaitu: kelerengan, kondisi geologi dan tanah, tataguna lahan, pola drainase, curah hujan, dan aktivitas manusia. Faktor dominan yang paling berpengaruh adalah: curah hujan harian yang ekstrim sebelum dan saat terjadi
\end{abstract}


longsor, jenis batuan vulkanik yang membentuk tanah sangat tebal dan gembur, dan kemiringan lereng yang curam-sangat curam. Analisis berbagai faktor penyebab longsor, zonasi tanah longsor serta analisis mekanisme longsor, akan sangat membantu dalam pananganan dan antisipasi bencana ke depan. Penataan kawasan pasca bencana longsor sangat diperlukan untuk bisa mengurangi risiko bencana serta membangun kawasan yang aman berkesinambungan. Banyak hal yang bisa dilakukan dalam penataan kawasan longsor tersebut antara lain adalah: daerah bekas dan rawan longsor dijadikan kawasan konservasi, relokasi penduduk yang terancam ke tempat yang aman, pengaturan drainase, penguatan tebing dan lereng jalan, menghindari tinggal pada lereng bukit serta alur sungai, penghijauan dengan tanaman yang keras dan berakar kuat. Pembentukan kesiapsiagaan masyarakat juga sangat dibutuhkan untuk membentuk masyarakat yang tangguh terhadap bencana tanah longsor.

Kata kunci: Sukajaya, longsor, curah hutan ekstrim, batuan dan tanah, penataan kawasan

\section{PENDAHULUAN}

Bencana tanah longsor (gerakan tanah) semakin sering terjadi di Indonesia akhirakhir ini, khususnya akibat curah hujan tinggi pada saat musim hujan. Kondisi tektonik aktif di Indonesia telah membentuk morfologi tinggi, patahan, batuan vulkanik dengan tingkat pelapukan yang tinggi dan mudah rapuh akibat iklim di Indonesia yang berupa tropis basah, sehingga menyebabkan potensi tanah longsor menjadi tinggi. Degradasi perubahan tataguna lahan yang terjadi akhir-akhir ini, menyebabkan bencana tanah longsor menjadi semakin meningkat. Kombinasi faktor anthropogenik dan alam sering merupakan penyebab terjadinya longsor yang memakan korban jiwa dan kerugian harta benda. Upaya mitigasi diperlukan untuk meminimalkan dampak yang terjadi akibat bencana longsor (Naryanto, 2013, hlm 2; Naryanto, 2017, hlm 2; Naryanto et al., 2017). Menurut Rahayu (2019, hlm 2), untuk mengurangi dampak negatif akibat longsor maka perlu diidentifikasi kawasan-kawasan yang rawan longsor sebagai antisipasi untuk mencegah kerugian yang lebih besar.

Jumlah bencana di Provinsi Jawa Barat khususnya Kabupaten Bogor cenderung meningkat setiap tahunnya. Dilihat dari sisi kondisi geografis, Kabupaten Bogor rentan dengan tanah longsor terutama pada saat musim hujan. Menurut BPBD Provinsi Jawa
Barat (2019), sebanyak 22 kota/kabupaten termasuk Kabupaten Bogor menjadi perhatian karena memiliki potensi longsor menengah hingga tinggi. Selain kejadian bencana tanah longsor di kawasan tersebut, sering juga ditambah dengan banjir bandang yang menyertainya.

Bencana longsor telah terjadi di Kecamatan Sukajaya, Kabupaten Bogor, Jawa Barat pada tanggal 1 Januari. 2020. Dari informasi BPBD Kabupaten Bogor, diberitahukan ada 8 orang menjadi korban longsor, di mana 6 orang di antaranya ditemukan meninggal dan 2 lainnya dinyatakan hilang. Curah hujan yang tinggi menjadi pemicu terhadap terjadinya bencana tanah longsor pada kawasan tersebut. Cuaca di lokasi pasca terjadi longsor saat itu kerap berubah dengan cepat, sehingga bahaya longsor susulan selalu mengancam di daerah tersebut. Beberapa kampung atau desa di Kecamatan Sukajaya banyak yang terisolasi akibat kejadian longsor tersebut (BPBD Kabupaten Bogor, 2020). Menurut PVMBG (2020), Secara umum longsor di Kabupaten Bogor 1 Januari 2020 tersebut terjadi karena interaksi kondisi geologi dan dipicu oleh curah hujan yang tinggi.

Kecamatan Sukaraja, Kabupaten Bogor terbentuk oleh morfologi yang bervariasi dari bergelombang sampai perbukitan. Selain itu kelerengan curam sampai sangat curam juga banyak dijumpai 
di kecamatan tersebut, sehingga menyebakan potensi bencana longsor tinggi. Dengan keterbatasan kawasan lahan datar dengan junlah penduduk yang padat di Kecamatan Sukajaya, menyebabkan banyak penduduk yang tinggal pada kawasan tebing atau lembah bukit yang rawan terhadap bencana tanah longsor.

Berdasarkan Peta Zona Kerentanan Gerakan Tanah Kabupaten Bogor dari Badan Geologi, lokasi gerakan tanah di Kecamatan Sukajaya termasuk dalam zona kerentanan gerakan tanah menengah sampai tinggi. Daerah pada zona kerentanan menengah sampai tinggi tersebut mempunyai potensi untuk terjadi gerakan tanah (longsor) menengah hingga tinggi. Pada zona ini dapat terjadi gerakan tanah jika curah hujan di atas normal, sedangkan gerakan tanah lama dapat aktif kembali (Djaja \& Suranta, 1996, hlm 1). Penelitian dari Badan Geologi di Kecamatan Sukajaya pad tahun 2018, menunjukkan sering terjadi tanah longsor yang diakibatkan adalah: oleh: pemotongan lereng yang tegak, kemiringan lereng yang curam, kondisi geologi berupa berupa breksi tuf dengan tanah pelapukan pasiran yang gembur, serta sistem drainase permukaan yang kurang baik (PVMBG, 2018, hlm 2).

Tanah longsor merupakan proses perpindahan massa batuan (tanah) akibat gaya berat (gravitasi). Longsor terjadi karena adanya gangguan kesetimbangan gaya yang bekerja pada lereng yakni gaya penahan dan gaya peluncur. Tanah longsor terjadi karena dua faktor utama yaitu faktor pengontrol dan faktor pemicu. Faktor pengontrol adalah faktor-faktor yang memengaruhi kondisi material itu sendiri seperti kondisi geologi, kemiringan lereng, litologi, sesar dan kekar pada batuan. Faktor pemicu adalah faktor yang menyebabkan bergeraknya material tersebut seperti curah hujan, gempabumi, erosi kaki lereng dan aktivitas manusia (Naryanto, 2017, hlm 2;
Naryanto et al., 2019a, hlm 273; Naryanto et al., 2019b, hlm 1054). Wang et al.(2017, hlm 1) mengatakan bahwa kejadian tanah longsor berhubungan dengan berbagai faktor seperti presipitasi, geologi, jarak dari patahan, vegetasi, dan topografi. Menurut PVMBG (2016, hlm 3), jenis tanah longsor berdasarkan kecepatan gerakannya dapat dibagi menjadi 5 (lima) jenis, yaitu: aliran, longsoran, runtuhan, amblesan, dan majemuk

Lokasi penelitian dilakukan pada lokasi di sekitar tanah longsor telah terjadi di di Kecamatan Sukajaya, Kabupaten Bogor, Jawa Barat, pada bulan Januari 2020. Maksud dari penelitian ini adalah untuk mengetahui kejadian bencana tanah longsor, dampak yang terjadi, faktor-faktor yang berpengaruh dan analisis mekanisme kejadiannya. Dengan diketahuinya permasalahan bencana tanah longsor tersebut, maka dapat dilakukan penataan kawasan yang diharapkan aman berkelanjutan terhadap bencana tanah longsor serupa di masa yang akan datang.

\section{METODE PENELITIAN}

Metode penelitian yang dilakukan secara umum adalah dengan metode pengumpulan data dan analisis data. Sedangkan metode analisis data dilakukan dengan analisis spasial, analisis data drone, dan analisis mekanisme longsor (Naryanto et al., 2019a, hlm 274; Naryanto et al., 2019b, hlm 1055).

\section{Metode Pengumpulan Data}

Metode pengumpulan data yang dilakukan adalah: persiapan dan koordinasi dengan instansi terkait, kajian data sekunder berkaitan dengan kajian penelitian terdahulu tentang longsor yang terjadi di Kecamatan Sukajaya (informasi dari penduduk, geologi, geomorfologi, struktur geologi, geologi tata lingkungan, geologi teknik, foto udara, curah hujan, DAS, hidrologi, drainase, sosial 
ekonomi, tata ruang atau RTRW, penggunaan lahan, data penduduk, foto udara, dan sebagainya), survei lapangan pasca bencana tanah longsor secara komprehensif (pengamatan dampak kejadian, luasan, kemiringan lereng, topografi, jenis litologi, tataguna lahan, kondisi hidrologi, curah hujan, mata air, DAS, tataguna lahan, jenis vegetasi, sosial ekonomi masyarakat, diskusi dengan masyarakat setempat, pemetaan longsor dengan drone), pengolahan data, analisis data, verifikasi data, serta analisis penataan kawasan pasca terjadinya longsor.

2. Metode Analisis Data

\subsection{Analisis Spasial}

Analisis spasial dilakukan pada lokasi penelitian untuk analisis peta kemiringan lereng dengan melakukan pengolahan data kontur rupabumi BIG Skala 1: 25.000 melalui extension spatial analyst pada software ArcGIS 10.6, sementara analisis peta sub DAS dengan melakukan pengolahan data kontur rupabumi BIG Skala 1:25.000 melalui software Global Mapper.

\subsection{Analisis Data Drone}

Metoda pembuatan foto udara menggunakan drone tipe DJI Inspire. Pengambilan data dengan menggunakan berbagai kamera digital: compact, mirrorless, SLR, video, built-in. Pengumpulan data juga dilakukan dengan melihat data peta yang dapat diakses dan digunatakan seperti google map, apple map, maverick dan data peta lainnya. Pemrosesan data otomatis sepenuhnya dengan perangkat lunak desktop khusus (bentley context capture, pix4dmapper, agisoft photoscan) atau layanan cloud computing. Alur metode pembuatan foto udara dengan drone adalah: penetapan lokasi target, pembuatan rencana terbang, pengambilan data dengan drone, pengolahan data dengan drone, pembuatan kontur dan pembuatan peta. Analisis peta penggunaan lahan dengan menggunakan citra hasil drone melalui software ArcGIS 10.6 untuk deliniasi wilayah terdampak longsor pada lokasi penelitian, sehingga dapat diidentifikasi sebaran permukiman, kerusakan akibat longsor dan untuk dasar perencanaan tata ruang selanjutnya.

\subsection{Analisis Mekanisme Longsor}

Analisis mekanisme kejadian longsor menggunakan beberapa parameter, yaitu: kondisi geologi, topografi, tataguna lahan, curah hujan, keairan dan drainase dan pengaruh aktivitas manusia. Mekanisme kejadian longsor sangat penting untuk pembelajaran dalam mengantisipasi kejadian serupa pada lokasi sekitar atau tempat lain.

\section{HASIL DAN PEMBAHASAN}

1. Kejadian Bencana Tanah Longsor di Kecamatan Sukajaya

Tanah longsor Kecamatan Sukajaya terjadi pada tangal 1 Januari 2020 secara masif dan serentak, terjadi puluhan sampai ratusan longsor dalam skala besar dan kecil hampir di seluruh kawasan kecamatan tersebut. Sebagian besar Kecamatan Sukajaya mempunyai morfologi bergelombang sampai perbukitan dengan kondisi kelerengan daerah yang terkena longsor curam sampai sangat curam. Batuan merupakan produk vulkanik, yang terbentuk oleh: breksi vulkanik, breksi andesit, tufa, batupasir tuffa, aliran lahar. Tingkat pelapukan batuan sangat tinggi, sehingga membentuk soil/tanah yang sangat tebal dan gembur (Gambar 1 dan Gambar 2). Vegetasi sebagian besar merupakan kebun campuran, sawah dan permukiman, banyak kasus pada lokasi kejadian tanah longsor, tanaman yang kuat dan rapatpun juga ikut terseret akibat longsor. 


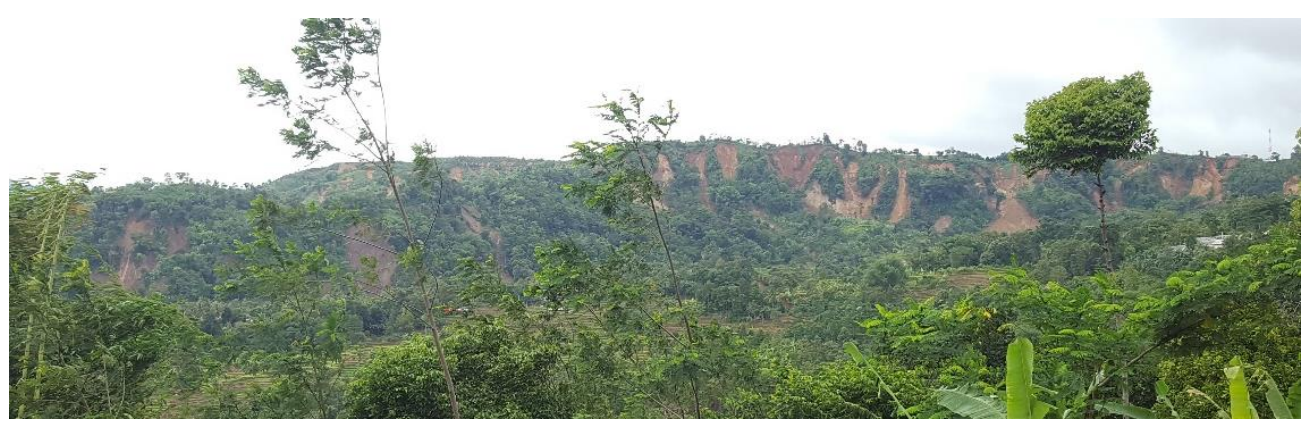

Gambar 1. Kejadian Longsor Masif dan Serentak di Sepanjang Bukit Desa Pasir Madang

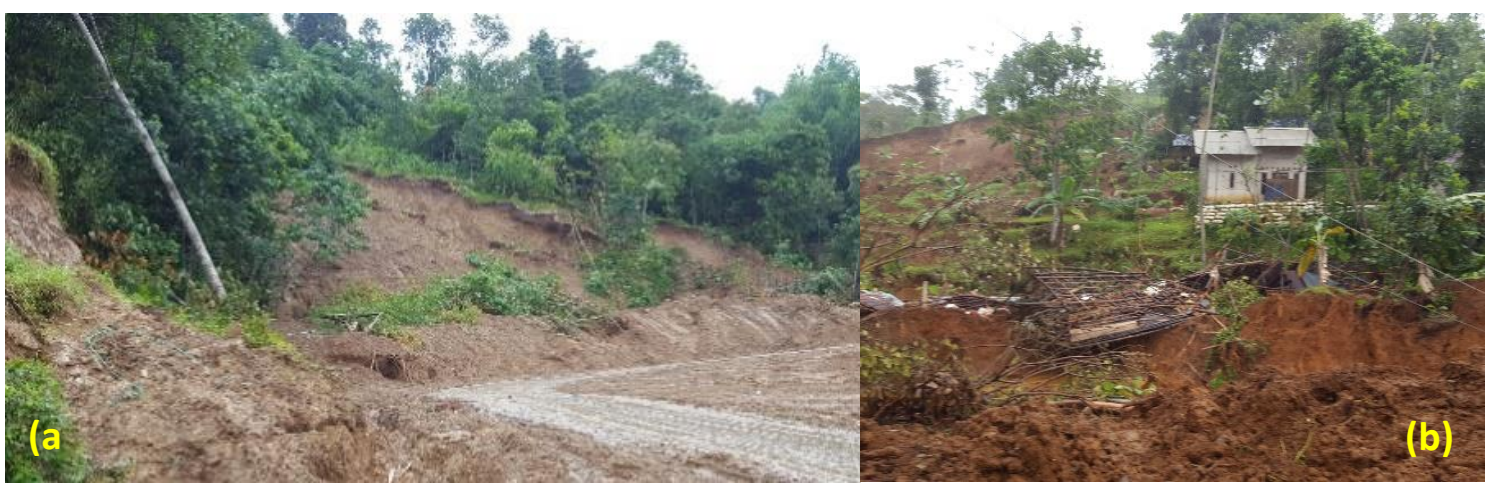

Gambar 2. Contoh-contoh Dampak Bencana Longsor di Desa Harkatjaya (a) dan Desa Pasir Madang (b)

Penduduk sebagian besar banyak yang tinggal pada kawasan rawan bahaya longsor, karena daerah aman terbatas dan sulit didapatkan. Relokasi sebenarnya beberapa sudah dilakukan dalam jumlah terbatas. Gangguan aktivitas manusia cukup besar dalam dalam mengelola lahan yang meningkatkan kejadian longsor.

Bencana longsor yang dipicu hujan dengan intensitas tinggi terjadi di Kecamatan Sukajaya, Kabupaten Bogor. Pada awal kejadian bencana tanah longsor, ada enam desa yang terisolasi, yaitu: Desa Kiarapandak, Desa Urug, Desa Kiarasari, Desa Cileuksa, Desa Cisarua, dan Desa Pasir Madang. Hampir semua desa di Kecamatan Sukajaya terkena dampak bencana tanah longsor. Bencana tanah longsor yang berdampak besar terhadap korban manusia dan infrastruktur terjadi di Desa Harkatjaya, Desa Pasir Madang, Desa Kiarapandak, dan
Desa Cileuksa (Naryanto et al., 2020, hlm 2).

2. Analisis Faktor-Faktor Penyebab Terjadinya Tanah Longsor di Kecamatan Sukajaya

Faktor-faktor yang menyebabkan terjadinya tanah longsor di Kecamatan Sukajaya, Kabupaten Bogor antara lain adalah: morfologi dan kelerengan, kondisi geologi dan tanah, tataguna lahan, pola drainase, curah hujan, dan aktivitas manusia.

a. Kelerengan

Analisis satuan kelerengan di Kecamatan Sukajaya menggunakan klasifikasi Van Zuidam (1983). Kecamatan Sukajaya banyak didominasi oleh kelerengan 15-70\%, kelerengan 7-15\% serta kelerengan $70-140 \%$. Secara detail kelerengan $30-70 \%\left(16^{\circ}-35^{\circ}\right)$ mempunyai 
luasan paling besar yaitu 7713,242 ha, diikuti dengan kelerengan 15-30 $\left(8^{\circ}-16^{\circ}\right)$ seluas 5274,378 ha, kelerengan $7-15 \%\left(4^{\circ}\right.$ $8^{\circ}$ ) seluas 1533,120 ha, dan kelerengan 70 $140 \% \quad\left(25^{\circ}-55^{\circ}\right)$ seluas 1500,353 ha. Kelerengan $>140 \%\left(>55^{\circ}\right)$ juga dijumpai dengan luasan 63,511 ha. Dari data tersebut didapatkan bahwa Kecamatan Sukajaya mempunyai daerah dengan kelerengan curam sampai sangat curam (di atas 30\%) besar, sehingga potensi untuk terjadi tanah longsor tinggi ditunjang dengan tingkat pelapukan tanah yang sangat tebal dan gembur.

Tabel 1. Hasil Analisis Luasan Kemiringan Lereng Kecamatan Sukajaya Kabupaten Bogor

\begin{tabular}{cccc}
\hline No & Kelas Lereng $(\%)$ & Kelas Lereng $\left({ }^{\circ}\right)$ & Luasan Area (Ha) \\
\hline 1 & $0-2 \%$ & $0-2$ & 114,118 \\
2 & $2-7 \%$ & $2-4$ & 349,645 \\
3 & $7-15 \%$ & $4-8$ & 1533,120 \\
4 & $15-30$ & $8-16$ & 5274,378 \\
5 & $30-70 \%$ & $16-35$ & 7713,242 \\
6 & $70-140 \%$ & $25-55$ & 1500,353 \\
7 & $>140 \%$ & $>55$ & 63,511 \\
\hline
\end{tabular}




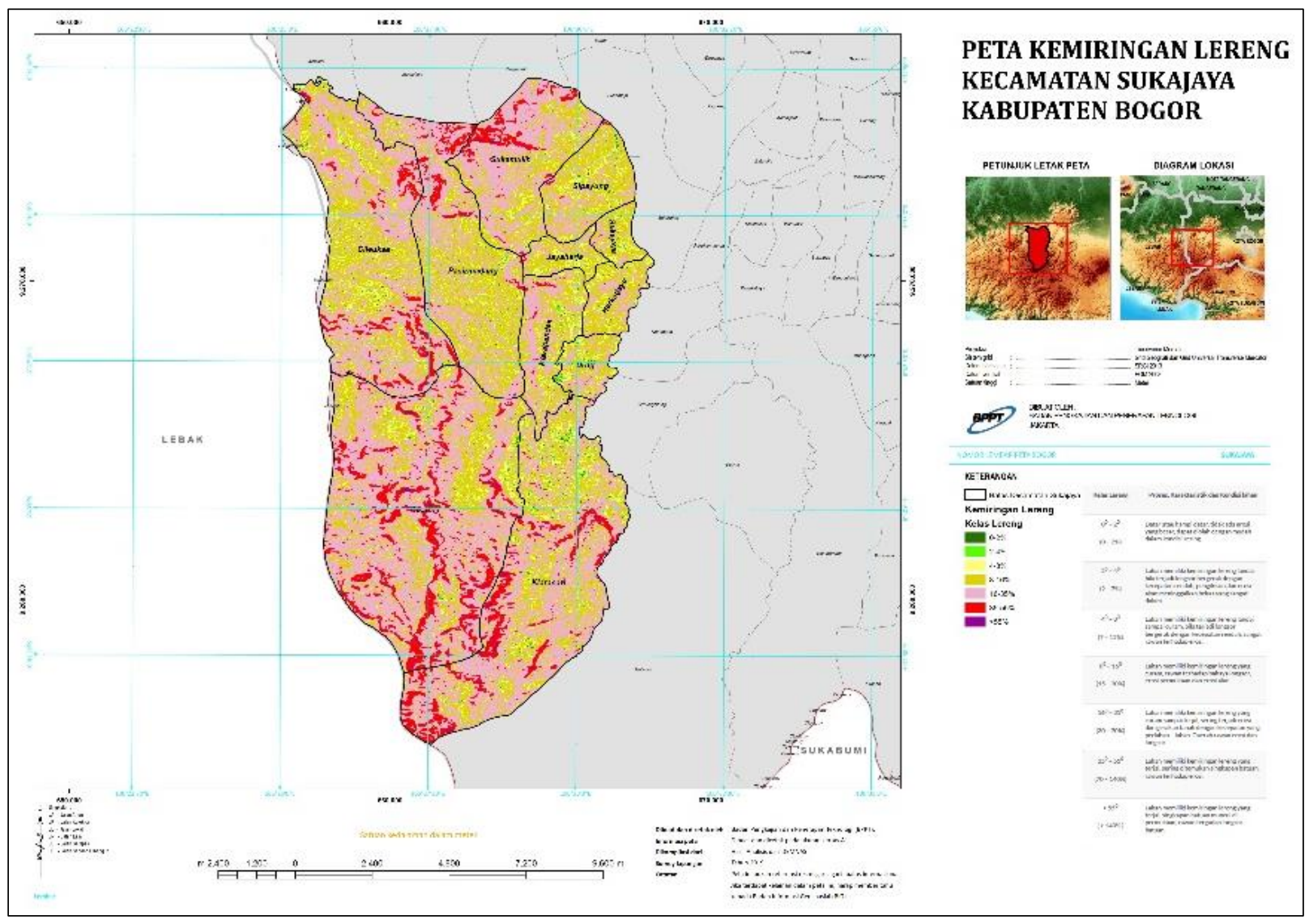

Sumber: Hasil Analisis (2020)

Gambar 3. Peta Kemiringan Lereng Kecamatan Sukajaya

b. Kondisi Geologi dan Tanah

Menurut peta geologi lembar Peta Geologi Lembar Leuwidamar (Sujatmiko \& Santosa, 1992, hlm 1) dan Peta Geologi Lembar Bogor (Effendi et al., 1996, hlm 1), jenis batuan yang terdapat di Kecamatan Sukmajaya adalah: Satuan Batuan Gunungapi Tak Tepisahkan (Qvu) yang merupakan breksi dan aliran lava, terutama andesit), Satuan Tuff dan Breksi (Tmtb) yang terdiri dari tuff batuapung, breksi tufan bersusunan andesit, batupasir tuf, lempung tufan dengan kayu terkesikkan dan sisa tumbuhan, batupasir berlapis silang, Satuan Batuan Gunungapi Endut (Qpv) yang tersusun oleh breksi gunungapi, lava, dan tuf, Formasi Bojongmanik (Tmb) yang terdiri dari batupasir, tuf batuapung, napal dengan Moluska, batugamping, batulempung dengan lempung bitumen dan sisipan lignit dan sisa damar, dan Satuan
Tuff Batuapung Pasiran dari Gunungapi Salak (Qv).

Batuan penutup berupa soil di bagian atas, berasal dari pelapukan batuan. Batuan banyak mengandung tufa dan material lain yang mudah lapuk, sehingga membentuk soil dengan ketebalannya sampai lebih10 meter. Lapisan soil kemudian bergradasi ke batuan breksi vulkanik yang relatif tidak terlapukan di bagian bawahnya (ukuran komponen antara pasir sampai dengan bongkah. Di bagian bawah material lapuk (soil) yang berupa batuan induk, terdapat bidang batas antara batuan lunak dan batuan keras yang berfungsi sebagai bidang gelincir longsor apabila terjadi kejenuhan akibat masuknya air ke dalam pori-pori tanah. Kejadian bencana tanah longsor semakin besar terjadi akibat kemiringan lereng yang sejajar dengan kemiringan batuan. 


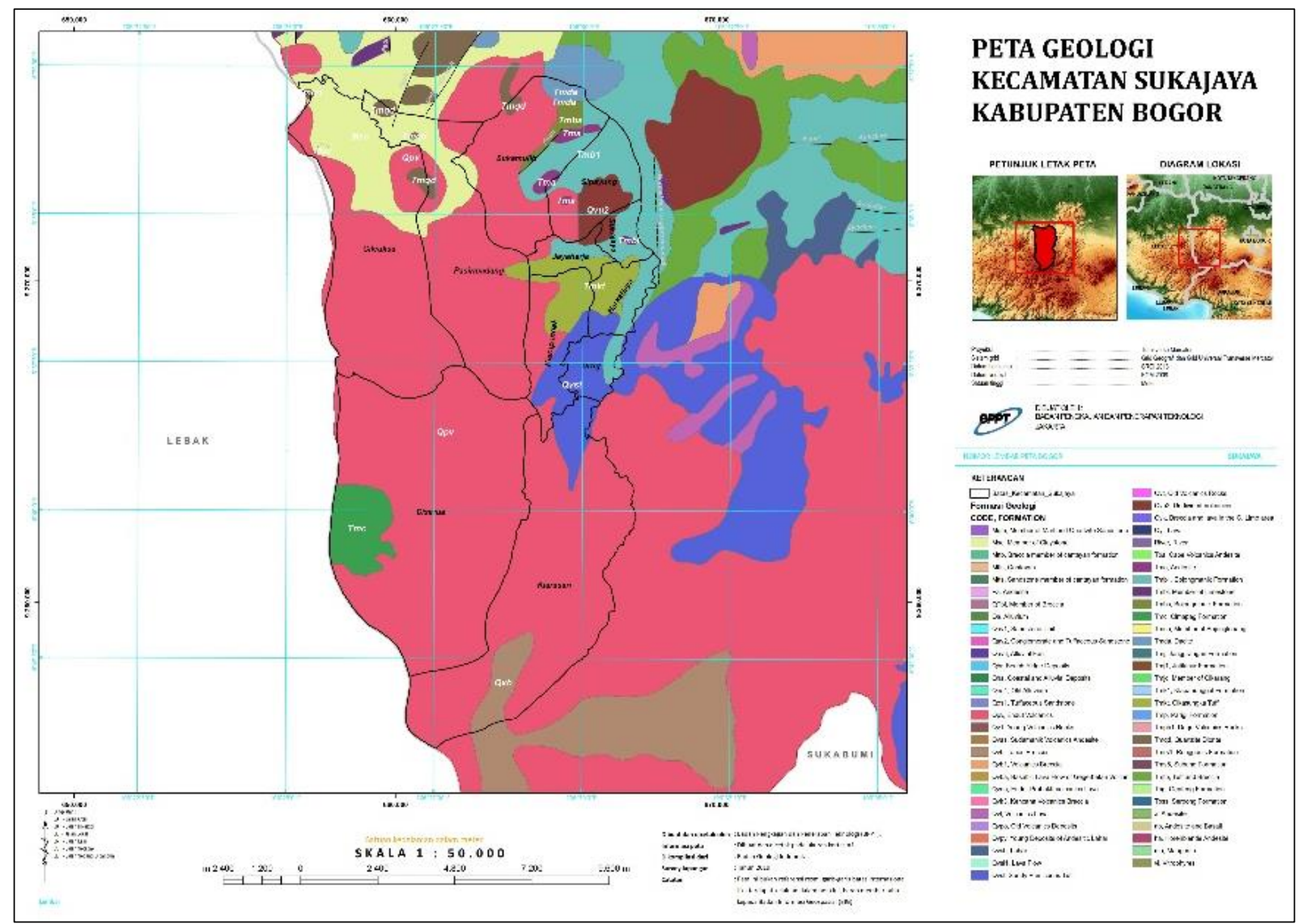

Sumber: Hasil Analisis (2020)

Gambar 4. Peta Geologi Kecamatan Sukajaya

\section{c. Tataguna Lahan}

Kelerengan lahan di Kecamatan Sukajaya tergolong curam hingga sangat curam, namun banyak dimanfaatkan oleh masyarakat untuk aktivitas budidaya pertanian mengingat tanahnya tergolong gembur dan subur. Tata guna lahan eksisting di lokasi longsor sebagian besar merupakan kawasan budidaya tanaman semusim pada lereng bukit membentuk teras teras. Selain tanaman semusim, di sebagian wilayah juga ditanami tanaman tahunan yang berakar kuat seperti pinus, mahoni, waru, durian, nangka, sengon, bambu dan sebagainya, dalam prespektif konservasi sangat membantu dalam mengurangi bahaya longsor.

Perubahan penggunaan lahan hingga mencapai puncak bukit untuk aktivitas berlangsung sangat intensif tanpa memperhatikan kaidah penggunaan lahan yang seharusnya sebagai kawasan lindung. 


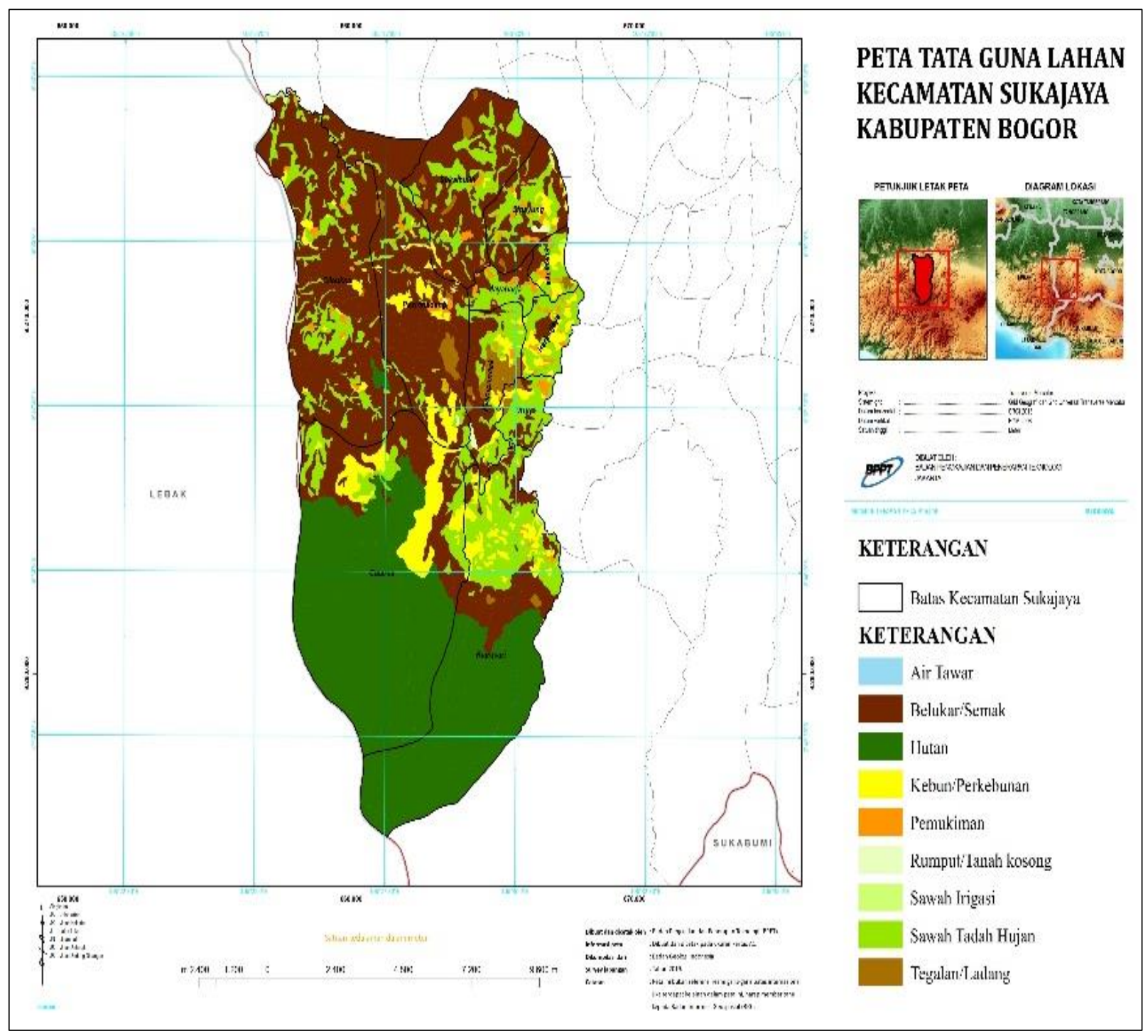

Sumber: Hasil Analisis (2020)

Gambar 5. Peta Tataguna Lahan Kecamatan Sukajaya

Tabel 2. Tataguna Lahan dan Luasannya di Kecamatan Sukajaya

\begin{tabular}{clr}
\hline No. & \multicolumn{1}{c}{ Keterangan } & Luas (Ha) \\
\hline 1 & Air Tawar & 9,5 \\
2 & Belukar/Semak & $6.697,1$ \\
3 & Hutan & $5.088,9$ \\
4 & Kebun/Perkebunan & $1.122,9$ \\
5 & Pemukiman & 267,4 \\
& Rumput/Tanah & \\
6 & kosong & 28,5 \\
7 & Sawah Irigasi & 34,4 \\
8 & Sawah Tadah Hujan & $2.991,3$ \\
9 & Tegalan/Ladang & 308,8 \\
\hline
\end{tabular}

Sumber: Hasil Analisis (2020) 
Tataguna lahan yang ada di Kecamatan Sukajaya secara detail terdiri dari: air tawar, belukar/semak, hutan, kebun/perkebunan, pemukiman, rumput/tanah kosong, sawah irigasi, sawah tadah hujan, dan tegalan/ladang. Semak belukar mempunyai luasan paling besar (6.697,1 ha), kemudian diikuti hutan campuran terletak di bagian selatan Kec. Sukajaya (5.089 ha), sawah tadah hujan (2.991,3 ha), kebun/perkebunan (1.122,9 ha), tegalan/ladang (308,8 ha), dan pemukiman (267,4 ha) (Gambar 5 dan Tabel 2).

\section{d. Sistem Tata Air}

Sistem drainase yang baik masih kurang diterapkan di kawasan longsor. Saluran-saluran buangan harus lebih banyak dibuat dalam rangka mengurangi kejenuhan tanah yang berdampak terhadap kestabilan lereng. Sistem drainase di permukaan dan jalan yang berfungsi untuk mengalirkan air dari kelebihan air hujan yang tidak terinfiltrasi oleh tanah. Sistem drainase ini mengumpulkan kelebihan air dilahan dan membuangnya dalam arah horisontal searah kontur dan tegak lurus kontur. Kondisi drainase tersebut kurang bagus, sehinga kelebihan air akibat hujan drainase yang tidak sempurna akan mengganggu kestabilan lereng dan mudah berdampak terhadap kejadian tanah longsor.

e. Curah Hujan

Data curah hujan Di Kecamatan Sukajaya pada tanggal 1 Januari 2020 menurut informasi BMKG adalah sebesar 301,6 mm/hari (PVMBG, 2020, hlm 2). Data curah hujan tersebut termasuk klasifikasi curah hujan sangat tinggi (ekstrim), dan curah hujan sebesar itu tidak pernah terjadi di Kecamatan Sukajaya selama ini. Curah hujan selama sehari tersebut hampir sama dengan data curah hujan selama sebulan.

\section{f. Aktivitas Manusia}

Ketidakseimbangan tanah akibat salah pengelolaan budidaya manusia yang secara kumulatif dapat memicu terjadi longsor. Secara umum kepala keluarga yang terkena bencana tanah longsor di Kecamatan Sukajaya memilki mata pencaharian bertani dan berkebun. Aktivitas manusia banyak berkaitan dengan pemotonan lereng, penggarapan lahan pada daerah miring yang kurang memperhatikan lingkungan, pemotongan jalan dengan kelerengan curam, penebangan tanaman keras, kurangnya reboisasi, dan sebagainya. Aktivitas masyarakat mempengaruhi terhadap kestabilan tanah dan bisa menyebabkan terjadinya tanah longsor (Gambar 6).

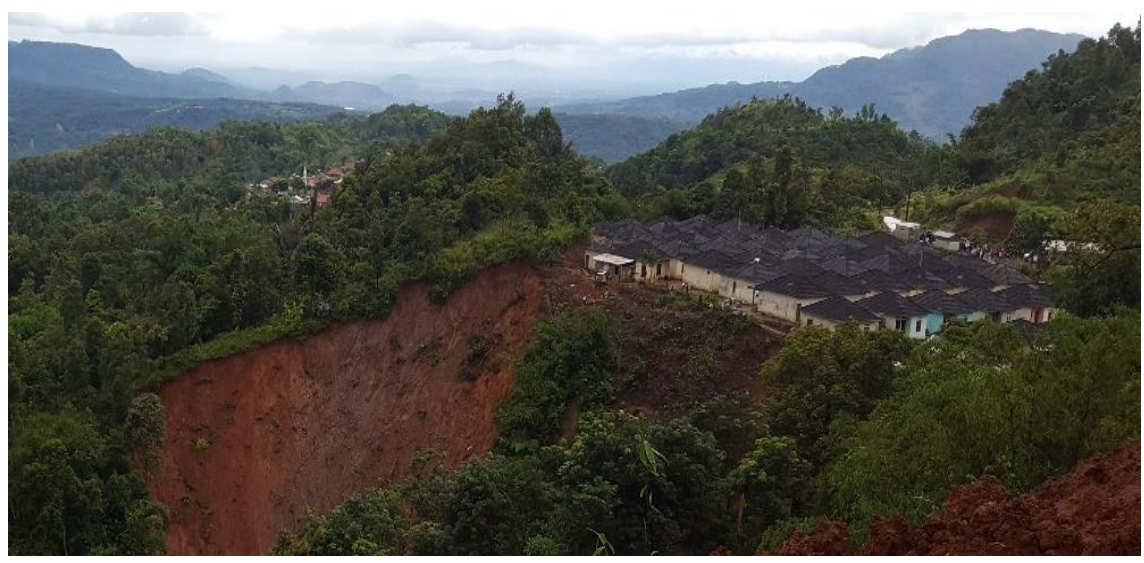


Gambar 6. Permukiman Relokasi yang Justru Terancam Longsor di Desa Pasir Madang

g. Faktor Utama yang Memepengaruhi Terjadinya Tanah Longsor

Dari keseluruhan faktor-faktor yang berpengaruh terhadap kejadian bencana longsor di Kecamatan Sukajaya, faktor dominan yang paling berpengaruh terhadap bencana longsor di Kecamatan Sukajaya adalah: (1) curah hujan harian yang ekstrim sebelum dan saat terjadi longsor (2) jenis batuan vulkanik yang tingkat pelapukan sangat tinggi yang membentuk tanah/soil sangat tebal (3) kemiringan lereng yang curam-sangat curam.

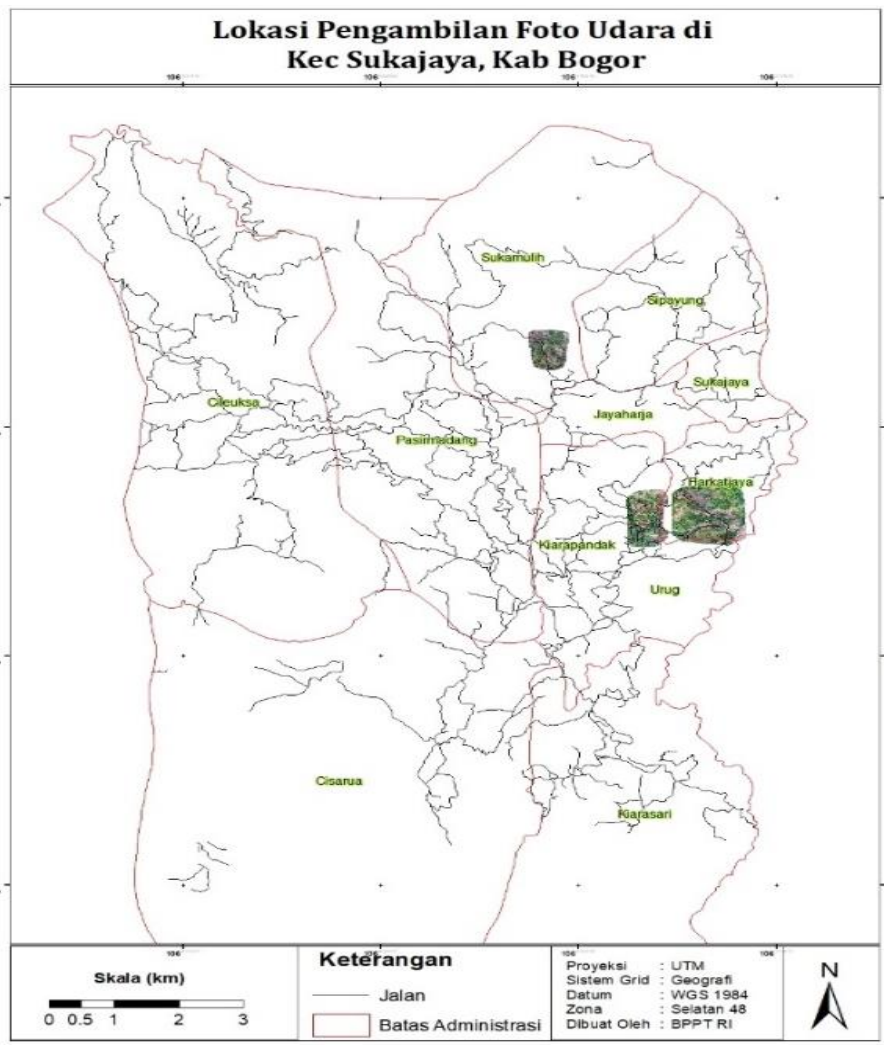

Gambar 7. Lokasi drone 3 Desa, yaitu di Desa Harkatjaya, Desa Kiarapandak dan Desa

Sukamulih, Kecamatan Sukajaya

3. Hasil Analisis Pemetaan Udara dengan

Data Drone

Pengambilan foto udara di Kecamatan Sukajaya dilakukan masih terbatas, yaitu hanya pada 3 desa, yaitu di Desa Harkatjaya, Desa Kiarapandak dan Desa Sukamulih
(Gambar 7). Aturan perijinan penerbangan drone dari ATC Atang Sanjaya sangat ketat mengingat padatnya lalu-lintas helikopter bantuan pada lokasi yang akses jalan masih tertutup.

Tabel 3. Tutupan Lahan Area Longsor di Desa Harkatjaya, Desa Kiarapandak dan Desa Sukamulih

\begin{tabular}{clc}
\hline No & Tutupan Lahan / Desa & Luas (Ha) \\
\hline A & Desa Harkatjaya & \\
1 & Hutan Rimba & 0.86
\end{tabular}




\begin{tabular}{llc}
2 & Perkebunan/Kebun & 3.95 \\
3 & Permukiman & 0.12 \\
4 & Sawah & 2.28 \\
5 & Tegalan/Ladang & 0.46 \\
B & Desa Kiarapandak & \\
1 & Perkebunan/Kebun & 0.31 \\
2 & Permukiman & 0.06 \\
3 & Sawah & 0.48 \\
4 & Semak Belukar & 0.29 \\
C & Desa Sukamulih & \\
1 & Perkebunan/Kebun & 0.82 \\
2 & Permukiman & 0.48 \\
\hline \multicolumn{2}{c}{ Sumber: Hasil Analisis (2020) }
\end{tabular}

Dari analisis yang diperoleh dengan mengoverlaykan data drone dengan tutupan lahan dan juga delineasi area longsor maka diperoleh hasil seperti pada Tabel 3. Hasil deliniasi pada area terdampak longsor di Desa Harkatjaya tutupan lahan yang terbesar adalah perkebunan (3.95 ha) dan sawah (2.28 ha), pada area longsor Desa

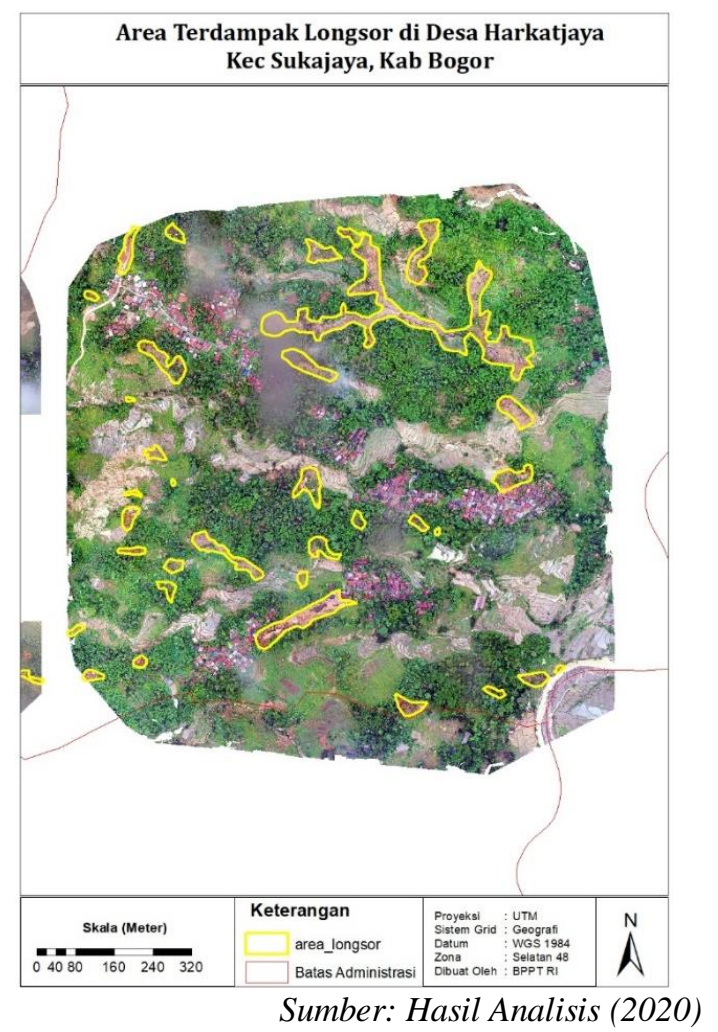

Gambar 8. Delineasi Area Longsor di Desa Harkatjaya Berdasarkan Foto Udara Drone
Kiarapandak tutupan lahan yang terbesar adalah sawah (0.31 ha) kemudian perkebunan (0.48 ha). Pada area longsor Desa Sukamulih tutupan longsor yang terbesar adalah perkebunan dan permukiman (Gambar 8, 9 dan 10 dan Tabel 3).

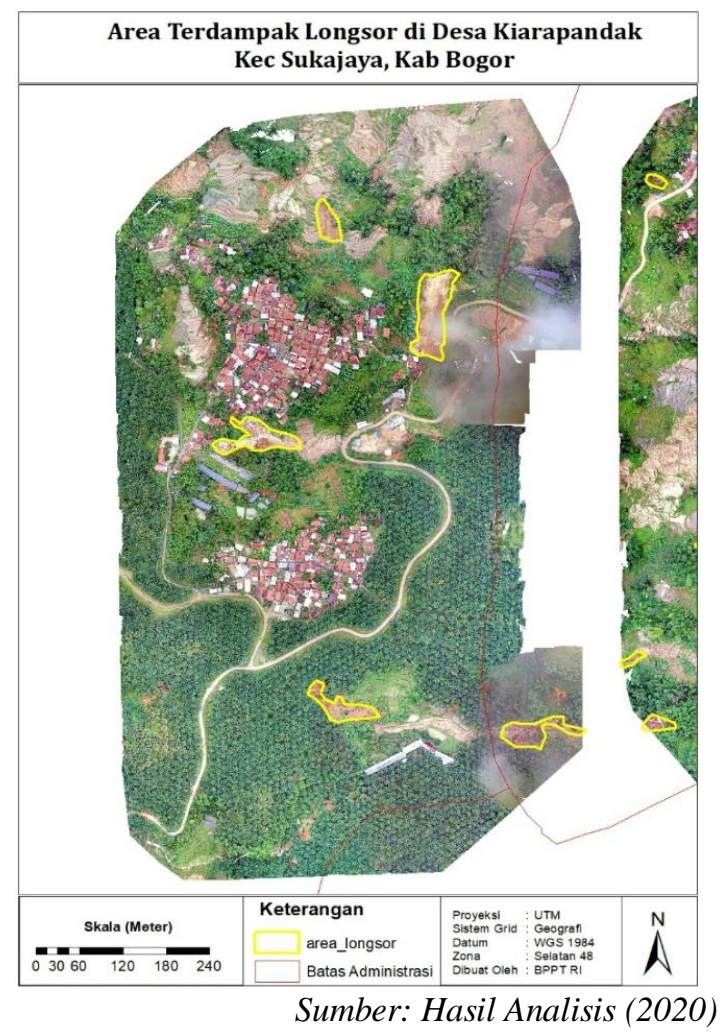

Gambar 9. Delineasi Area Longsor di Desa Kiarapandak Berdasarkan Foto Udara Drone 


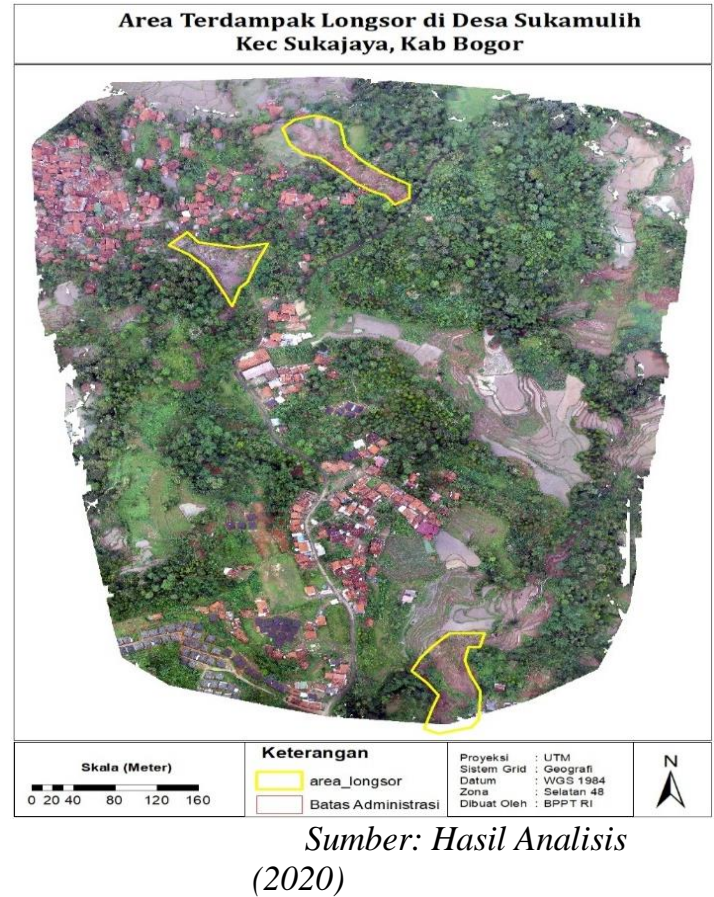

Gambar 10. Delineasi Area Longsor di Desa Sukamulih Berdasarkan Foto Udara Drone

\section{Mekanisme Kejadian Tanah Longsor}

Dari banyak faktor yang berpengaruh terhadap bencana tanah longsor, khususnya adalah topografi yang curam serta tipe tanah (soil) yang sangat tebal dan gembur. Dengan curah hujan harian ekstrim di Kecamatan Sukajaya yang dimulai pada tanggal 31 Desember 2019 dan meningkat tinggi pada 1 Januari 2020, kondisi lereng pada banyak lokasi di Kecamatan Sukajaya khususnya yang curam sampai sangat curam menjadi tidak stabil dan terjadi banyak sekali kejadian tanah longsor dari skala kecil sampai besar. Tanah longsor Kecamatan Sukajaya terjadi secara bersamaan, hampir bersamaan, serta longsor susulanm sehingga banyak menimbulkan korban baik jiwa maupun harta. Tipologi tanah longsor Kecamatan Sukajaya sebagian besar berupa longsoran bahan rombakan (debris slide), yang membentuk bekas longsor seperti kenampakan tapal kuda dari mahkota sampai kaki longsor, kemudian di beberapa tempat karena material longsor bercampur air dalam jumlah besar berkembang menjadi aliran bahan rombakan (debris flow). Pada beberapa tempat dijumpai tipe tanah longsor berupa nendatan (creep).

\section{Penataan Kawasan Pasca Bencana} Tanah Longsor di Kecamatan Sukajaya Dominasi batuan yang ada di Kecamatan Sukajaya sebagian besar merupakan produk vulkanik, mempunyai tingkat pelapukan sangat tinggi sehingga menyebakan produk tanah yang sangat tebal, gembur dan rapuh dan rawan terhadap longsor. Daerah yang terjadi bencana longsor 1 Januari 2020 memang semuanya terdapat pada lokasi yang rawan longsor. Lokasi tempat tinggal yang aman terhadap longsor di Kecamatan Sukajaya sulit didapatkan dan menjadi kendala tersendiri. Daerah permukiman terdampak serta rawan longsor sebaiknya dikosongkan dan penghijauan kembali kawasan tersebut akan bisa menambah daerah resapan yang bisa menahan air untuk disimpan ke dalam tanah. Daerah tersebut sebaiknya dijadikan kawasan konservasi, yang terbebas dari aktivitas permukiman, pertanian, dan infrastruktur penting lainnya. Penghijauan juga segera dilakukan pada kawasan yang terkena dampak longsor di sekitar permukiman untuk meresapkan air permukaan dalam rangka mengurangi bahaya longsor.

Menurut Glade (2003, hlm 298) dan Naryanto et al. (2020, hlm 1062), perubahan penggunaan lahan merupakan faktor pemicu penting terjadinya bencana longsor. Penggunaan lahan dengan vegetasi berperakaran dangkal berkontribusi terhadap ketidakstabilitas lereng. Interaksi hutan dengan kejadian longsor merupakan fenomena yang kompleks. Semakin rapat proporsi tutupan hutan, maka semakin rendah jumlah lereng/tanah yang tererosi oleh hujan.

Penghijauan kembali adalah salah satu solusi yang harus dilakukan pada kawasan yang rawan dan bekas longsor. Penghijauan dilakukan dengan tanaman yang keras dan berakar kuat pada kawasan lereng curam yang cocok pada daerah 
tersebut. Banyak tanaman lokal yang sudah ada di daerah tersebut dan ini bisa dikembangkan untuk konservasi daerah tersebut. Tanaman-tanaman tersebut antara lain adalah: cempedak, sukun, nangka, damar, bambu, kaliandra, sonokeling, akasia, angsana, kayu manis, durian, lamtoro, sengon, pinus, mahoni, dan sebagainya. Tanaman vetiver yang berupa serai wangi/akar wangi bisa dicoba untuk dikembangkan di daerah tersebut dengan mempertimbangkan contoh sukses tanaman tersebut di daerah lain.

Banyak permukiman penduduk di Kecamatan Sukajaya, termasuk Desa Harkatjaya, Desa Kiarapandak dan Desa Sukamulih yang sudah dilakukan pemetaan dengan drone, telah mengalami bencana dan rawan terhadap tanah longsor. Relokasi penduduk terancam tanah longsor merupakan salah satu cara untuk menyelamatkan masyarakat, dan pemilihan kawasan relokasi yang aman harus berdiskusi dengan para ahli.

Untuk jangka pendek masyarakat harus menghindari tinggal pada lereng bukit curam yang borpotensi longsor, baik di bagian atas lereng, pada lereng bukit, lembah dari bukit yang curam, serta pada alur sungai. Aktivitas masyarakat di sekitar lokasi tersebut akan menambah beban yang berakibat stabilitas lereng menjadi terganggu. Daerah lereng curam, lembah dan alur sungai berpotensi menjadi jalan pergerakan material longsoran pada saat atau setelah hujan dengan intensitas tinggi.

Sebagian jalan di sepanjang Desa Harkatjaya, Kiarapandak, Desa Pasir Madang, Desa Cileuksa, dan lainnya banyak yang tertutup oleh bencana tanah longsor 1 Januari 2020. Sebagai evaluasi, untuk pembuatan jalan yang berada pada batas bukit dan lembah curam, sebaiknya pemotongan lereng jalan diusahakan tidak curam supaya tidak mudah longsor yang menimbun jalan dan menutup akses transportasi. Pelebaran jalan sangat diperlukan, sekaligus dilakukan penguatan tebing dengan konstruksi struktur beton yang kuat serta pada tebing bekas terjadinya longsor.

Kondisi tata air dan drainase yang ada di Kecamatan Sukajaya saat ini sebagian besar kurang tertata rapi. Perlu direncanakan ke depan untuk pembuatan drainase di bawah tebing hasil pelebaran jalan baru, goronggorong pembuangan dari saluran drainase yang memotong jalan untuk disalurkan ke tempat yang lebih rendah, drainase pada bukit di atas jalan, serta permukiman. Mata air yang muncul di beberapa lokasi menjadi berkah tersendiri buat masyarakat untuk kehidupan sehari-hari, tetapi perlu juga harus hati-hati pada saat debit tinggi karena curah hun yang tinggi. Saluran drainase yang baik sangat diharapkan untuk secepatnya membuang air tersebut ke arah saluran di bawahnya, supaya tidak menggenang dan menjenuhi tanah yang meningkatkan potensi terhadap longsor.

Untuk mempersiapkan masyarakat dalam meningkatkan kesiapsiagaan sebagai upaya pengurangan risiko bencana tanah longsor di Kecamatan Sukajaya, beberapa hal yang perlu dilakukan antara lain adalah: pembentukan team siaga bencana tanah longsor tingkat desa atau dukuh/kampung, memperkuat kesiapsiagaan masyarakat serta aparat serta rencana kontigensi terhadap kegiatan di sekitar longsor terutama saat dan setelah terjadi hujan yang tinggi atau berlangsung lama, melakukan gladi dan sosialisasi bencana tanah longsor, pembangunan sistem peringatan dini bahaya tanah longsor baik yang berbasis masyarakat maupun instrumen khususnya berbasis curah hujan atau Automatic Weather Station (AWS) khususnya pada kawasan permukiman yang berisiko tinggi, serta pemasangan peta bahaya longsor, jalur evakuasi, dan rambu-rambu peringatan rawan longsor pada jalur jalan dan pada tempat-tempat yang rawan longsor.

\section{SIMPULAN}

Tanah longsor Kecamatan Sukajaya tangal 1 Januari 2020 terjadi secara masif dan serentak, hampir di seluruh kawasan 
kecamatan tersebut. Tipologi tanah longsor sebagian besar berupa longsoran bahan rombakan, berkembang menjadi aliran bahan rombakan, sementara di beberapa tempat dijumpai tipe tanah longsor berupa nendatan. Banyak faktor yang menyebabkan terjadinya tanah longsor di Kecamatan Sukajaya, yaitu: kelerengan, kondisi geologi dan tanah, tataguna lahan, pola drainase, curah hujan, dan aktivitas manusia. Faktor dominan yang paling berpengaruh terhadap bencana longsor adalah: kemiringan lereng yang curamsangat curam, jenis batuan vulkanik yang tingkat pelapukan sangat tinggi yang membentuk tanah sangat tebal, dan curah hujan harian yang ekstrim sebelum dan saat terjadi longsor.

Penataan kawasan pasca longsor dibutuhkan dalam perencanaan pembangunan yang aman berkelanjutan. Daerah permukiman terdampak serta rawan longsor sebaiknya dikosongkan dan dijadikan kawasan konservasi. Relokasi penduduk terancam tanah longsor merupakan salah satu cara untuk menyelamatkan masyarakat, dan pemilihan kawasan relokasi yang aman harus berdiskusi dengan para ahli. Penghijauan dilakukan dengan tanaman yang keras dan berakar kuat pada kawasan lereng curam yang cocok pada daerah tersebut. Perlu dihindari permukiman pada lereng bukit curam yang berpotensi longsor, baik di bagian atas lereng, pada lereng bukit, lembah dari bukit yang curam, serta pada alur sungai.

Pembuatan jalan yang berada pada batas bukit dan lembah curam, sebaiknya pemotongan lereng jalan diusahakan tidak curam supaya tidak mudah longsor yang menimbun jalan dan menutup akses transportasi. Kondisi tata air dan drainase yang ada di Kecamatan Sukajaya saat ini sebagian besar kurang tertata rapi, sehingga perlu pembuatan drainase di bawah tebing hasil pelebaran jalan baru, gorong-gorong pembuangan dari saluran drainase yang memotong jalan untuk disalurkan ke tempat yang lebih rendah, drainase pada bukit di atas jalan, serta permukiman.

\section{REKOMENDASI}

Masyarakat di Kecamatan Sukajaya perlu mempersiapkan kesiapsiagaan terhadap bencana tanah longsor yang antara lain: pembentukan team siaga bencana, membangun rencana kontigensi, gladi dan sosialisasi, membangun sistem peringatan dini, pemasangan peta, jalur evakuasi, rambu, dan sebagainya. Pemetaan udara dengan drone di Kecamatan Sukajaya secara detail sangat diperlukan untuk penanganan pasca longsor, mitigasi bencana, sebagai referensi instansi terkait dalam rangka mempercepat proses pembangunan. Selain itu juga perlu dilakukan kajian pemetaan risiko bencana tanah longsor secara detil level Kecamatan Sukajaya yang meliputi: bahaya, kerentanan dan risiko untuk masukan terhadap evaluasi tata ruang kawasan yang aman berkesinambungan.

\section{DAFTAR PUSTAKA}

BPBD Provinsi Jawa Barat. (2019). Data Bencana Provinsi Jawa Barat Tahun 2019. Tersedia https://jabarprov.go.id, diakses pada 13 Januari 2020.

BPBD Kabupaten Bogor. (2020). Data Bencana Tanah Longsor Kecamatan Sukajaya, Kabupaten Bogor. Tersedia di https://bpbd.bogorkab.go.id/, diakses pada 25 Januari 2020.

Djaja \& Suranta. (1996). Peta Zona Kerentanan Gerakan Tanah Lembar Bogor, Jawa, Badan Geologi. Tersedia di https://vsi.esdm.go.id/gallery/index.php? /search/101617, diakses pada 13 Januari 2020.

Effendi, A.C., Kusnama \& Hermanto, B. (2011). Peta Geologi Lembar Bogor, Jawa, Badan Geologi. 
Glade T. (2003). Landslides Occurrence as Response to Land Use Change: A Review of Evidence from New Zealand. Catena. (51): 297-314, tersedia

di

https://homepage.univie.ac.at/thomas. glade/Publications/Glade2003a.pdf.

Naryanto, H.S. (2013). Analisis dan Evaluasi Kejadian Bencana Tanah Longsor di Cililin, Kabupaten Bandung Barat, Provinsi Jawa Barat Tanggal 25 Maret 2013. Jurnal Sains dan Teknologi Mitigasi Bencana. 8(1): 39-49.

Naryanto, H.S. (2017). Analisis Kejadian Bencana Tanah Longsor di Dusun Jemblung, Desa Sampang, Kecamatan Karangkobar, Kabupaten Banjarnegara, Provinsi Jawa Tengah Tanggal 12 Desember 2014. Jurnal Alami. 1(1): 1-9, DOI: https://doi.org/10.29122/alami.v1i1, tersedia di http://ejurnal.bppt.go.id/index.php/Ala mi/issue/view/175.

Naryanto, H.S., Soewandita, H., Ganesha, D., Prawiradisastra, F. \& Kristijono, A. (2019). Analisis Penyebab Kejadian dan Evaluasi Bencana Tanah Longsor di Desa Banaran, Kecamatan Pulung, Kabupaten Ponorogo, Provinsi Jawa Timur Tanggal 1 April 2017, Jurnal Ilmu Lingkungan, 17 (2): 272 - 282, doi:10.14710/jil.17.2.272-282, tersedia di

\section{https://ejournal.undip.ac.id/index.php/il} mulingkungan/issue/view/2650.

Naryanto HS, Prawiradisastra F, Kristijono A, Ganesha D. (2019). Penataan Kawasan Pasca Bencana Tanah Longsor di Puncak Pass, Kecamatan Cipanas, Kabupaten Cianjur Tanggal 28 Maret 2018. JPSL 9(4): 1053-1065, http://dx.doi.org/10.29244/jpsl.9.4.10531065, tersedia di https://journal.ipb.ac.id/index.php/jpsl /issue/view/2548.

Naryanto, H.S, Prawiradisastra, F., Ardiyanto, R., dan Hidayat, W. (2020). Kajian Tanah Longsor di Kecamatan Sukajaya, Kabupaten Bogor, BPPT, Laporan, tidak diterbitkan.

PVMBG. (2016). Gerakan Tanah, Buklet Gerakan Tanah. Tersedia di http://pvmbg.geologi.esdm.go.id/index.p $\mathrm{hp} /$ kegiatan-pvmbg/downloadcenter/cat view/88-publikasi/114leafletbooklet, diakses pada 2 Februari 2020.

PVMBG (2018). Laporan Singkat Pemeriksaan Gerakantanah Di Kec. Sukajaya, Kab. Bogor Provinsi Jawa Barat, Laporan, 17 hal. Tersedia di https://vsi.esdm.go.id/index.php/geraka n-tanah/kejadian-gerakan-tanah/1937laporan-singkat-pemeriksaangerakantanah-di-kec-sukajaya-kab-bogorprovinsi-jawa-barat, diakses pada 10 Januari 2020.

PVMBG (2020). Laporan Pemeriksaan Gerakan Tanah di Kecamatan Sukajaya, Kabupaten Bogor Provinsi Jawa Barat, Laporan, 10 hal. Tersedia di

https://vsi.esdm.go.id/index.php/geraka n-tanah/kejadian-gerakan-tanah/2981laporan-pemeriksaan-gerakan-tanah-dikecamatan-sukajaya-kabupaten-bogorprovinsi-jawa-barat, diakses pada 13 Januari 2020.

Rahayu, A.M.U, Ardiansyah, A.N., Nuraeni, N.S. (2019). Wilayah Kerawanan Longsor di Kecamatan Pamijahan Kabupaten Bogor. Jurnal Geografi Gea, 19(1): 1-8, DOI: doi.org/10.17509/gea.v19i1.18493, tersedia di https://ejournal.upi.edu/index.php/gea/art icle/view/13862. 
Sujatmiko \& Santosa. (1992). Peta Geologi Lembar Leuwidamar, Jawa, Badan Geologi

Wang F, Xu P, Wang C, Wang N, Jiang, N. (2017). Application of a GIS-based slope unit method for landslide susceptibility mapping along the Longzi River, Southeastern Tibetan Plateau, China. ISPRS International Journal of Geo-Information. 6(6): 172, tersedia di https://www.mdpi.com/22209964/6/6/172

Van Zuidam, R.A. (1983). Guide to Geomorphology Aerial Photographic Interpretation and Mapping, ITC, Enschede, The Netherlands. 